Since it is really the objective theory which selects as well as interprets the terms of a contract when writing is involved, the place of the parol evidence rule in the law of contracts is clear. It is a restatement of the objective theory for a select group of cases.

\title{
CONTRACTION OF FEDERAI JURISDICTION: CONVENIENCE OR NECESSITY?
}

While events national and international do steadily press our people into a closer union, the national courts alone make their possibly gallant, but surely eventually futile, attempts to restore states-rightism.

-CLARK, J.

Thus did one of the nation's eminent jurists rebuke a majority of his court for a new contraction of federal jurisdiction in favor of state courts. The national courts do seem to be making an effort to contract their jurisdiction, if not to "restore states-rightism." Arguably, the greatly increased scope of federal activities may warrant such a result. Federal dockets are overcrowded with cases arising under federal statutes. Part of the total burden could be removed by deferring to the state courts in specific areas. Such action might make for greater harmony between the two systems and add to the dignity of the federal courts. ${ }^{2}$ Congressional determination of federal jurisdiction, however, sets a definite limit on the extent to which federal courts may contract their jurisdiction in accordance with their own views of convenience and the federal-state relationship.

A contraction of federal jurisdiction may be desirable in certain situations

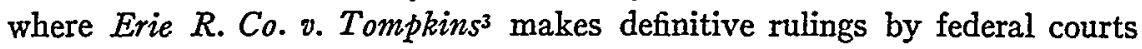
impossible. In cases where its jurisdiction is based solely on diversity of citizenship, a federal court, under the Erie doctrine, must look to the law of the state in which it sits for its rules of decision (except for questions involving the federal constitution or statutes). Even when the rule of the state is unsettled, the federal court must still, in theory at least, apply what it finds the state law to be. ${ }^{4}$ Unlike the case of a state court's ruling on a federal question, however, a federal court's determination of state law cannot be appealed to the state supreme court. An anomalous situation may arise in which a state issue is adjudicated by the federal court, only to be decided differently thereafter in the state

× Beiersdorf v. McGohey, I87 F. 2d 14, I7 (C.A. 2d, I951).

${ }^{2}$ Frankfurter, Distribution of Judicial Power Between the United States and State Courts, I3 Cornell L.Q. 499 (I928).

${ }^{3} 304$ U.S. 64 ( 1938 ).

4 Cities Service Oil Co. v. Dunlap, 308 U.S. 208 (I939); McClare v. Mouton, I23 F. $2 d 45^{\circ}$ (C.A. Ioth, I94I); Federal Court's Disposition of Unsettled Questions of State Law, How a Federal Court Determines State Law, 48 Col. L. Rev. 575 (1948); How a Federal Court Determines State Law, 59 Harv. L. Rev. 1299 (1946). 
courts. Since one aim of the Erie doctrine is the securing of uniformity in the law, ${ }^{5}$ it is not surprising that federal jurisdiction has been curtailed where there is a possibility that this problem might arise.

An analogous problem arises when an unconstrued state statue or its enforcement is alleged to be unconstitutional. Here, unlike cases of simple diversity, the presence of a federal question will always provide a basis for federal jurisdiction. ${ }^{6}$ Nevertheless, the basic problem is the same. The federal court faces the possibility of deciding a constitutional issue raised by a state statute which the state courts may construe so as to avoid the constitutional problem entirely. Since under standard canons of statutory interpretation, federal courts avoid unnecessary constitutional decisions, ${ }^{7}$ federal jurisdiction has been curtailed here too. A similar curtailment has occurred where other fields of state endeavor have been declared, either by congressional or judicial fiat, to be more properly adjudicated in the first instance in the state courts. ${ }^{8}$

The abolition of diversity jurisdiction 9 and a rule forbidding federal courts to take jurisdiction over matters involving unconstrued state statutes provide obvious solutions to the problems just raised..$^{\text {xo }}$ But until very recently the courts have had to content themselves with the few exceptions to general rules of federal jurisdiction carved out by Congress and a rather piecemeal solution evolved from the cases. The basic problem remains in many areas.

Although federal diversity jurisdiction is sometimes spoken of as an absolute right, ${ }^{\mathrm{II}}$ it is in reality a statutory grant dating from the Judiciary Act of $\mathrm{I} 789 .^{\mathrm{I2}}$ Federal question jurisdiction dates from the Act of March 3, $1875 .{ }^{13}$ Prior to that time, such cases were pursued in the state courts and reviewed in the United States Supreme Court under Section 25 of the Judiciary Act of $1789 .{ }^{.44}$ Until relatively recently the federal courts carefully guarded the legislative

5 See Guaranty Trust Co. of New York v. York, 326 U.S. 99, I08 (I945); Moore, Judicial Code 3 I7 (I949).

${ }^{6}$ The problem here exists independent of Erie R. Co. v. Tompkins, since even under the doctrine of Swift v. Tyson, I6 Pet. (U.S.) I (I842), the federal courts were bound by the state courts' interpretation of the state statutes.

7 Alma Motor Co. v. Timken-Detroit Axle Co., 329 U.S. 229 (x946).

8 One possible explanation for the jurisdictional curtailments, however, must not be overlooked. The main purpose of the federal courts in contracting their jurisdiction may be to relieve their crowded dockets, or, in the case of the Supreme Court, to protect its power over its own docket. This latter is especially true where there is an appeal as a matter of right. See Stainback v. Mo Hock Ke Lok Po, 336 U.S. 368, 375 (r950).

9 See Burford v. Sun Oil Co., 3I9 U.S. 315, 336 (1943) (dissent of Justice Frankfurter); Frankfurter, op. cit. supra note 2; Federal Jurisdiction-Effect of Undetermined State Law, 7 Univ. Chi. L. Rev. 727 (1940).

ro See Alabama Public Service Comm'n v. Southern Ry. Co., 34I U.S. 34x, 35 I (I95I) (concurring opinion of Justice Frankfurter); Editorial, I8 Case and Comment 28 (IgII).

Ix See Checker Cab Mfg. Co. v. Checker Taxi Co., 26 F. 2d 752 (N.D. Ill., I928) (constitutional right of federal jurisdiction).

${ }^{21}$ I Stat. 73 (I789), as amended, 28 U.S.C.A. § I332 (1950).

$x_{3}$ I S Stat. 470 (Vol. 3) (r875). ${ }^{14}$ I Stat. 85 (I789). 
grant of jurisdiction, and the first exceptions came from Congress. The "ThreeJudge Court Act," ${ }^{\prime}{ }_{5}$ first passed in I9I0, requires that all federal suits to enjoin the operation or enforcement of a state statute alleged to violate the Constitution of the United States be heard by a district court of three judges, one of whom shall be a circuit judge. Direct appeal to the Supreme Court is a matter of right. ${ }^{16}$ This act was not originally directed at the problem of state-federal court relationships; it was an attempt to prevent lower federal courts from excessive interference with state legislation in certain "sensitive" areas. ${ }^{x 7}$ By the inconvenience it has caused the parties and judges, the Three-Judge Court Act has resulted in some lessening of the number of cases involving unconstrued state statutes. ${ }^{8}$ But as a means of combatting the general problem raised by such cases, the act is haphazard and inefficient. Congress' passage of the Johnson $\mathrm{Act}^{19}$ and the Anti-Tax Injunction Act ${ }^{20}$ indicates that the Three-Judge Court Act was felt to be inadequate. The Johnson Act forbids federal district courts to take jurisdiction of suits to enjoin orders of state public utility rate-making boards if the state remedy is "plain, speedy and efficient." Similarly, the AntiTax Injunction Act forbids jurisdiction to enjoin the assessment, levy, or collection of a state tax when the state provides "a plain, speedy and efficient remedy." In these two areas, a party can reach a federal court only by an appeal from the highest state court to the United States Supreme Court.

These Acts of Congress aside, the federal courts have taken it upon themselves to limit the exercise of their own jurisdiction. ${ }^{21}$ They have been quicker to recognize their jurisdiction than to grant and exercise it. At one pole, the clearest statement of the recognition of the duty to exercise a well-pleaded jurisdiction is found in Meredith v. Winter Haven. ${ }^{22}$ Here, jurisdiction was based on both

${ }^{15} 36$ Stat. 539 (rgro), as amended, 28 U.S.C.A. § $228 \mathrm{I}$ ( $195^{\circ}$ ).

${ }^{36} 36$ Stat. II $5 \circ$ (I9I0), as amended, 28 U.S.C.A. $\$$ I253 (I950). For this reason, the act is now construed with the intention of protecting the appellate docket of the Supreme Court. See Stainback v. Mo Hock Ke Lok Po, $33^{6}$ U.S. 368,375 (1950). If this is a proper analysis of the recent three-judge court cases, then their value as precedents has been misunderstood. In East Coast Lumber Terminal v. Babylon, 174 F. 2 d 106 (C.A. 2d, I949), an action to enjoin the enforcement of a city ordinance (and for that reason not requiring a special three-judge court), Judge Learned Hand applied the rules as formulated in the three-judge cases to deny federal jurisdiction, although the decision could have little or no effect on the appellate docket of the Supreme Court.

17 The fear was not that the federal dockets were too crowded but that federal judges were too eager to enjoin even valid state statutes and administrative orders. Moore, Judicial Code I-54 (I949); Hutcheson, A Case for Three Judges, 47 Harv. L. Rev. 795 (I934); Warren, Federal and State Court Interference, 43 Harv. L. Rev. 345 (I930).

${ }^{88}$ See Stratton v. St. Louis Southwestern Ry. Co., 282 U.S. Io (I930); Moore, Judicial Code I3I (I949); Hutcheson, op. cit. supra note r6. But see Stainback v. Mo Hock Ke Lok Po, 336 U.S. 368,375 (r950).

${ }^{39} 48$ Stat. 775 (1934), 28 U.S.C.A. \& $1_{342}$ (I950).

${ }^{20}$ 5o Stat. 738 (I937), 28 U.S.C.A. \& r34I (I950).

2x This trend is comparatively new and parallels significantly the tremendous increase in federal legislation in recent times.

${ }^{22} 320$ U.S. 228 (I943). 
diversity and the presence of a substantial federal question (the constitutionality of a state statute). The Supreme Court held that the district court could not decline to exercise its jurisdiction merely because difficult and complicating questions of state law were involved. ${ }^{23}$ But this rule was already riddled with exceptions which the court duly proceeded to list. ${ }^{24}$ The exceptions were cast in the form of instances in which a federal court in equity should, in its discretion, deny or delay the exercise of its jurisdiction pending some action in the state courts. This discretion arose from general equitable powers and was not thought to apply generally to all federal cases, ${ }^{25}$ even though almost identical problems might arise in suits at law.

Probably the most venerable of these exceptions relates to suits to enjoin state criminal proceedings: Jurisdiction could be exercised only to prevent "irreparable injury which is clear, imminent, and substantial." ${ }^{26}$ Of course, if doubt exists as to a crucial interpretation of state law, "injury is not clear,"27 and since it is rarely "imminent" if there is a suit to enjoin in the state court, federal courts have shown a great reluctance to act at all in this area. ${ }^{28}$ The

${ }_{23}$ " [T] state law to be do not in themselves afford a sufficient ground for a federal court to decline to exercise its jurisdiction to decide a case which is properly brought to it for decision. ... The diversity jurisdiction was not conferred for the benefit of the federal courts or to serve their convenience. Its purpose was generally to afford to suitors an opportunity in such cases, at their option, to assert their rights in the federal rather than in state courts." Ibid., at 234. Compare Cowling v. Deep Vein Coal Co., I83 F. 2d $65_{2}$ (C.A. 7 th, 1950).

The district judges have had difficulty in applying this rule, e.g., Sussman v. Escambia County, 88 F. Supp. 480 (N.D. Fla., I950); and the Supreme Court has had its troubles too. See Propper v. Clark, 337 U.S. 472, 486-92 (r949). There, the Court relied on the special competence of the lower federal courts in determining questions of state law. Rulings "by federal courts skilled in the law of particular states" would not be overruled "unless their conclusions [are] shown to be unreasonable." Ibid., at 486-87.

24 Meredith v. Winter Haven, 320 U.S. 228, 23 I (1943).

${ }_{25}$ "This use of the equitable powers is a contribution of the courts in furthering the harmonious relationship between state and federal authority without the need of rigorous congressional restriction of these powers." R.R. Comm'n of Texas v. Pullman Co., 3I2 U.S. 496, 500 (I94I).

${ }^{26}$ Beal v. Missouri Pacific R. Corp., 3I 2 U.S. 45 (r94I); Hague v. CIO, 307 U.S. 496 (I939).

${ }^{27}$ In this situation, the practice seems to be for the court to take jurisdiction but delay its exercise until the statute has been construed in the state court. AFL v. Watson, 327 U.S. 582 (I946); Chicago v. Fieldcrest Dairies, 316 U.S. I68 (r942); United Electrical R. \& M. Workers v. Baldwin, 67 F. Supp. 235 (Conn., 1946).

${ }^{28}$ The more usual practice is to deny jurisdiction entirely. Douglas v. Jeanette, 3 rg U.S. ${ }_{57}$ (1943); Watson v. Buck, 3 I $3_{3}$ U.S. 387 (I94I); Beal v. Missouri Pacific R. Corp., 3I2 U.S. 45 (r940); Miami v. Sutton, I8I F. 2 d 644 (C.A. 5 th, I950); Bratley v. Nelson, 67 F. Supp. 272 (S.D. Fla., I946).

In Merced Dredging Co. v. Merced County, 67 F. Supp. 598 (S.D. Cal., I946) the conditions for exercising jurisdiction were met when there were threats of numerous criminal prosecutions, risk of fine and imprisonment, and threatened damage to the plaintiff's property for which there was no one who could be compelled to respond. Also see Truax v. Raich, 239 U.S. 33 (1915) where the result of the federal court's failure to exercise its jurisdiction would have been loss of employment by plaintiff or criminal prosecution of his employer. 
reasoning behind this restraint on jurisdiction is twofold. In the case of an unsettled state issue or an unconstrued statute, complications arise because the determinative law can only be authoritatively announced by the state courts. If the question is not as to the meaning of the criminal statute involved, but rather a question of its enforcement, the courts reason that this is a matter of strictly local policy, which should, in deference to the federal-state system, be decided upon in the first instance by local courts. The usual solution to these problems is a denial or a stay of federal jurisdiction.

Similar reasoning helps explain the familiar rule denying federal jurisdiction before all state administrative remedies have been exhausted. ${ }^{29}$ Federal courts have also precluded themselves, as equity courts of first instance, from the important area of state fiscal policy..$^{30}$ Since Congress has expressly denied them a part of this area by statute, ${ }^{3 \mathrm{x}}$ one might argue that the courts would be bound to operate wherever the congressional limitation did not apply. But the Supreme Court, in Spector Motor Service v. McLaughlin, ${ }^{32}$ has extended the limitation imposed by the Anti-Tax Injunction Act to cover cases in which the state remedy is not certain, on the grounds that if the court ruled on the constitutionality of the state tax before its coverage was fully determined by the state court, the federal court might be making an unnecessary constitutional decision. ${ }^{33}$

29 Prentis v. Atlantic Coast Line, 2 I I U.S. 210 (xg08); Chambless v. Cannon, 8 I F. Supp. 885 (W.D. Ark., I949). But see Hillsboro v. Cromwell, 326 U.S. 620 (I946) (administrative remedies exhausted since opportunity to apply to appeal board had expired). Of course, these cases do not present the problem of federal-state court relationships in any pure form, since the same rule is applied as between federal courts and federal administrative agencies and between state courts and state administrative agencies.

Similarly, federal courts will refuse congressionally authorized jurisdiction in an action under the Bankruptcy Act where only issues of state law are to be determined. Thompson v. Magnolia Co., 309 U.S. 478 (r940). See also Pennsylvania v. Williams, 294 U.S. 176 (1935) (liquidation of an insolvent state bank by state officials). And the federal courts must refrain from exercising jurisdiction to interfere with a uniform state regulatory policy. Burford v. Sun Oil Co., 3I9 U.S. 3I5 (I943) (oil proration order involving state conservation policy). Contra: Parker v. Brown, 39 F. Supp. 895 (S.D. Calif., I94I), rev'd on other grounds, $3^{\mathrm{I}} 7$ U.S. $34 \mathrm{I}$ (1942).

${ }^{30}$ Spector Motor Service v. McLaughlin, 323 U.S. Ior (1944). Accord: Boyce v. Buscoglia, 77 F. Supp. 753 (Puerto Rico, 1948).

${ }^{31}$ Anti-Tax Injunction Act, 50 Stat. 738 (I937), 28 U.S.C.A. § I34I (I950).

${ }^{37} 323$ U.S. Ior (I944).

33 The history of the Spector case exemplifies the tremendous waste of time and energy that can result from the Supreme Court's timidity in making "unnecessary" constitutional decisions. The District Court had originally granted the injunction. The Supreme Court remanded the cause to the District Court with directions to retain the bill pending the determination of proceedings to be brought in the state courts. The Supreme Court of Errors of Connecticut held that the petitioner was subject to the tax, but refused to pass on the effect of the Commerce Clause, the basis of the constitutional question. Thus the case came back to the Supreme Court through the federal courts. In Spector Motor Service v. O'Connor, $34 \circ$ U.S. 602 (I95I) the Supreme Court held the application of the tax to the petitioner invalid. This was seven years after the first Supreme Court case. 
Probably the broadest statement of the rule underlying most of the exceptions to the Winter Haven case is found in Texas Railroad Comm'n v. Pullman, ${ }^{34}$ a three-judge court case. A state administrative order allegedly resulted in unconstitutional discrimination in railroad employment. The Supreme Court thought that the federal equity court should exercise its discretion to hold in abeyance its jurisdiction over a case involving a "sensitive area of social policy ... unless no alternative to its adjudication is open." 35 Again, the purpose was the prevention of an "unnecessary decision" by the federal courts. Of course an alternative method of obtaining relief exists within the state courts in such situations; and therefore the only thing required to defeat the immediate exercise of federal jurisdiction is a "sensitive area of social policy." ${ }^{6}$

The broad scope of the Pullman cases ${ }^{37}$ is reaffirmed by the recent Supreme Court decision in Alabama Public Service Comm'n v. Southern Ry. Co. ${ }^{38}$ a suit to enjoin the state commission from enforcing its ruling denying the petitioner the right to discontinue two passenger trains. On the grounds that intrastate railroad service regulation is "primarily the concern of the state" 39 and that

${ }^{34} 3$ I2 U.S. 496 (194ז).

$35 \mathrm{Tbid}$., at 498 . This follows from the so-called rule of abstention: federal courts will not interfere in the state process where their discretion as courts of equity allows them to deny the remedy asked. "Abstention" is less a rule, however, than a statement of principle from which more particularized rules are drawn. The use of the word "discretion" seems to be misleading, for actually the rules, both for exercising and not exercising jurisdiction, seem hard and fast. Meredith v. Winter Haven, 320 U.S. 228 (I943).

${ }^{36}$ Congress has found such "sensitive" areas in both public utility rate making and state tax matters. See text and notes at notes 19,20 , and $3 \mathrm{r}$ supra. On the other hand, Congress has also outlined at least one area in which the jurisdiction is not to be defeated in the manner under discussion. 36 Stat. 1092 (I9II), as amended, 28 U.S.C.A. $\S \mathrm{r}_{343}$ (I95) gives original jurisdiction, to the federal courts, of any case brought to redress a violation of civil rights, irrespective of the amount involved, and 36 Stat. 1096 (IgII), as amended, 28 U.S.C. A. \$ I443 (1950) provides for the removal of a civil action or a criminal prosecution by a defendant who is denied his civil rights. The courts seem to have interpreted this mandate broadly. Goesaert v. Cleary, 335 U.S. 464 (I948); Hague v. CIO, 307 U.S. 496 (x939); Birmingham v. Monk, r85

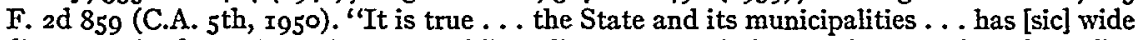
discretion in determining its own public policy.... But it is equally true that the police power ... is not above the Constitution." Ibid., at 861; Butler v. Thompson, 184 F. 2d 526 (C.A. 4th, I950); Manchester v. Leiby, II7 F. 2d 66I (C.A. Ist, I94I). But see Cooper v. Hutchinson, I84 F. $2 \mathrm{~d}$ II9 (C.A. $3 \mathrm{~d}$, I950), where the district court was ordered to retain jurisdiction of an injunction matter until the state law as to an accused's right to an out-of-state counsel was determined in order to avoid an unnecessary constitutional decision.

${ }^{37}$ The force of the Pullman case as a precedent is weakened, however, by the fact that the lower federal courts have not been shocked into submission by the broad language used in the case. See for instance the following district court cases: Southern Ry. v. Alabama Public Service Comm'n, 9I F. Supp. 980 (M.D. Ala., I950); Ann Arbor R. Co. v. Michigan Public Service Comm'n, 9I F. Supp. 668 (E.D. Mich., I950); Mo Hock Ke Lok Po v. Stainback, 74

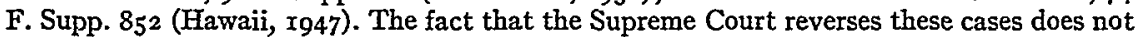
necessarily guarantee that the number of them going to the Supreme Court will be appreciably lessened in the future.

${ }^{38} 34 \mathrm{x}$ U.S. $34 \mathrm{I}$ (x95 I).

${ }^{39}$ Ibid., at 346 ; North Carolina v. United States, 325 U.S. 507, 5 II (x945). 
adequate review of the administrative order was available in the state courts, $4^{\circ}$ the Court ordered the district court to withhold the exercise of its jurisdiction as a matter of sound equitable discretion. Probably Justice Frankfurter is correct when he states, in his concurring opinion, that " $[t]$ he only reason for declining to entertain the suit is that it may be more desirable as a matter of StateFederal relations for the order of a State agency to be reviewed originally in the State lower court and not to be challenged in the first instance in the federal court." $4 x$

Of course, if the state law on the subject is clear, i.e., the statute in question has already been construed by the state court, the Winter Haven rule is given full play.42 Other grounds for not invoking any of the exceptions to the Winter Haven rule include the inadequacy of the state remedy; 43 the danger of a multiplicity of suits; ${ }^{44}$ the law in question being the law of a state other than the one in which the federal court is sitting; $; 5$ the state statute in question clearly dealing with a field which a federal statute has preempted; $4^{6} \mathrm{a}$ clear congres-

${ }^{40}$ Alabama Public Service Comm'n v. Southern Ry. Co., 34I U.S. 34I, 348 (I95I). The state statute merely gave an appeal to a state court as a matter of right. There was no hint that such appeals are ever denied in any state. Justice Frankfurter, in his concurring opinion, said that this would make it impossible for any federal court ever to entertain a suit against any action of a state agency. Ibid., at 362 .

$4^{\mathrm{x}}$ Ibid., at $3^{6 \mathrm{r}}$. Sometimes the denial of federal jurisdiction seems a necessity. See Paris v. Metropolitan Life Ins. Co., I67 F. 2d 834 (C.A. 2d, 1948), where federal jurisdiction would have opened the defendant to a very real threat of criminal prosecution.

The broad language of the Southern Railway case may not be followed in all its ramifications by the lower federal courts and three-judge courts in particular. Perhaps the Supreme Court cases present a distorted picture of actual lower court practice. See cases cited note 37 supra. It is not to be doubted that a similar discontinuance case would receive the same treatment by any federal court, but the extension to all cases arising out of state administrative determinations is dubious. The lower courts seem more concerned with the congressional mandate than does the Supreme Court, and for this reason the lower courts might be expected to continue to apply the traditional rules of federal jurisdiction, within very broad limits, even in the face of the line of cases from Pullman through Southern Railway. Of course, if the number of precedents becomes sufficiently large, the lower courts will undoubtedly fall in line. But since a decision on a jurisdictional question occupies as much of the court's time as one on the merits, and does not necessarily preclude the latter, the Supreme Court's inclination to decide cases in this fashion may lessen. See the dissenting opinion in Spector Motor Service v. O'Connor, 340 U.S. 602 (195I).

${ }_{42}$ In re Central R. Co. of N.J., I63 F. 2 d 44 (C.A. 3 d, I947). This case and the cases cited below through note 49 deal with civil suits exclusively. The difficulty in getting federal jurisdiction over state criminal matters has been pointed out above. See text and notes at notes 26 through 28 supra.

${ }^{43}$ Hillsboro v. Cromwell, 326 U.S. 620 (I945); Truax v. Raich, 239 U.S. 33 (Igr5).

44 R.R. Comm'n of Texas v. Pullman, 3I2 U.S. 496 (I94I). But see Di Giovanni v. Camden Ins. Ass'n, 296 U.S. 64 (I935) (two suits not a multiplicity).

45 Janes v. Sackman Bros. Co., I77 F. 2d 928 (C.A. 2d, I949); Pan American Airways v. Consolidated Vultee Corp., 87 F. Supp. 926 (S.D.N.Y., I949).

${ }_{46}^{6}$ First Iowa Hydro-Electric Cooperative v. FPC, 328 U.S. I52 (1946) (state law not clear but the Court held that Congress had intended the FPC to have comprehensive control, and any interference by the states could be enjoined in a federal court). But see Rice v. Santa Fe Elevator Corp., 33 I.S. 218 (1947). 
sional direction that certain rights are to be enforced in the federal courts; $; 7$ and a prior interpretation by another state of a statute identical to the one in question..$^{8}$

The source of the exceptions to the Winter Haven rule has been found in the inherent power of a court of equity to decline to grant or exercise its jurisdiction at its discretion. But this circumstance results in an incongruity: the rules of jurisdiction as between state and federal courts vary as the matter is directed at the law or equity side of the Court. ${ }^{9}$ In the past, the jurisdictional problem was greater on the law side of the court because courts of law were not thought to have inherent discretion to deny jurisdiction over matters properly before them. Yet the development at law has been similar to that in equity, for it was recognized very early that a court of the United States "like other courts, has power to postpone the trial of a case for good reason." ${ }^{50}$ This freedom to postpone, however, has been more carefully checked than the analogous discretion of the chancellor. ${ }^{\text {II }}$ It may be exercised only to postpone an action, whereas in equity, jurisdiction may be denied altogether. However, if an action at law is postponed pending the outcome of a state suit, the state court judgment would probably bar further action in the federal court on the ground of res judicata. ${ }^{52}$ The power to postpone becomes the power to deny.

At one time it was considered an unauthorized abandonment of jurisdiction to hand a civil diversity case over to the state courts. ${ }^{53}$ This is no longer true. In cases where a critical issue is the proper construction of a state constitution or statute, the federal court is said to have power to defer the issue to the state courts. ${ }^{54} \mathrm{~A}$ federal action for a declaratory judgment is also deferred to state

47 First Iowa Hydro-Electric Cooperative v. FPC, 328 U.S. I52 (I946); Markham v. Allen, 326 U.S. 490 ( 1946 ).

${ }^{48}$ Shipman v. Du Pre, 88 F. Supp. 482 (E.D.S.C., I950), rev'd 339 U.S. 32 (I950); Steed v. Dodgen, 85 F. Supp. $95^{6}$ (W.D. Tex., 1949).

${ }^{49}$ If the motivation for the decisions which have been examined is a desire to lighten federal dockets, an extension of the limitations would be expected in cases at law. See note 8 supra.

so McClellan v. Carland, $2 \times 7$ U.S. 268, 282 (rgro) (though admitting, at 283 , that the "rule is well recognized that the pendency of an action in the state court is no bar to proceedings concerning the same matter in the Federal court having jurisdiction"). "The power to stay proceedings is incidental to the power inherent in every court to control the disposition of the causes on its dockets with economy of time and effort for itself, for counsel, and for litigants." Landis v. North American Co., 299 U.S. 248, 254 (I936). See also Butler v. Judge of United States District Court, rr6 F. 2d Ior3 (C.A. 9th, r94I).

sx General Outdoor Advertising Co. v. Williams, I2 F. 2d 773 (C.A. Ist, I943).

- $\quad{ }^{2}$ McClellan v. Carland, 2 I7 U.S. 268 (rgro).

53 Ibid., at 28I: "It therefore appeared upon the record presented ... that the Circuit Court had practically abandoned its jurisdiction over a case of which it had cognizance, and turned the matter over for adjudication to the state court. This . . a Federal court may not do." Ibid., at 28x.

54 In Mottolese v. Kaufman, 176 F. 2d zor, 302 (C.A. 2d, I949), Judge Learned Hand cites as authority for this proposition United States v. City of New York, I75 F. 2 d 75 (C.A. 2 d, 
courts when another suit presenting the same issues is pending in the state court. 55 And the rule of exhaustion of administrative remedies applies equally in law as in equity..$^{56}$

Of late, the circumstances under which federal jurisdiction may be avoided in proceedings at law have been broadly expanded. The now famous case of Mottolese v. Kaufman, ${ }^{57}$ a stockholders' derivative suit, held that the pending of an identical suit in a state court and general inconvenience to the parties and the avoidance of a multiplicity of 'suits were sufficient "positive reasons" why a diversity suit should have its disposition in the federal court stayed. ${ }^{8}$ The case might have been limited to its peculiar fact situation, ${ }^{59}$ but Judge Frank in Beiersdorf v. McGohey, ${ }^{60}$ a patent infringement suit, stated that "the considered rationale of the majority in Mottolese was so sweeping that it should not be avoided merely on the basis of the different facts here."6x Aside from the fact that in both cases a prior suit was pending in the state court and the district courts were congested, such "positive reasons" as were listed in the Mottolese case seemed lacking. ${ }^{62}$ Nevertheless, if some of the language used by Judge Hand in Mottolese is valid, a change has indeed occurred in the rule. ${ }^{63}$ With regard to

r949) and East Coast Lumber Terminal v. Babylon, r74 F. 2d ro6 (C.A. 2d, I949) (cited note I6 supra). The first of these is a suit on a petition for a declaratory judgment in a tax matter, and the second is clearly in equity.

s5 Brillhart v. Excess Ins. Co., 3 I6 U.S. 49r (r94I). "Where a District Court is presented with a claim such as was made here, it should ascertain whether the questions in controversy between the parties to the federal suit, and which are not foreclosed upon the applicable substantive law, can better be settled in the proceeding pending in the state court." Ibid., at 495. See also McLain v. Lance, $x_{4} 6$ F. $2 d$ 34r (C.A. $5^{\text {th }}$, r944). And see Meredith v. Winter Haven, 320 U.S. 228, 23I (1943), where the Court said that "although the opinion below refers to the suit as one for a declaratory judgment ... so far as we are concerned ... the case does not differ from an ordinary equity suit. ..."

${ }^{6}$ See first three cases cited note 29 supra.

57 I 76 F. 2 d 3 or (C.A. 2d, I949).

${ }^{8}$ Mottolese v. Kaufman, I76 F. 2d $30 x$ (C.A. 2d, r949). Citing Gulf Oil Corp. v. Gilbert, 330 U.S. 50r (I947) and Koster v. Lumberman's Mutual Ins. Co., 330 U.S. 5 I8 (I947), the court said that a federal action dependent on diversity is always subject to the plea forum non conveniens, "and from this it follows that a federal suit, which has been brought after a state suit, may be stayed, for we can see no difference in kind between the inconveniences which may arise from compelling a defendant to stand trial at a distance from a place where the transactions have occurred, and compelling him to defend another action on the same claim." Tbid., at 303 .

s9 Beiersdorf v. McGohey, I87 F. 2d I4, I7 (C.A. 2d, I95I) (Judge Clark's dissent), noted in 38 Geo. L.J. 303 (I950), 63 Harv. L. Rev. 893 (I950), 2 Stanf. L. Rev. 399 (I95O).

$60 \times 87$ F. 2 d 14 (C.A. $2 d, x_{95}$ ).

6 Ibid., at I5.

${ }^{62}$ As a precedent this case may be very weak, since Judge Frank admits that he still considers the decision in the Mottolese case to be wrong. It is possible that Judge Frank actually hopes to have the rationale of the Mottolese case overruled, and that he tagged an apparently incorrect decision onto Beiersdorf in order to attain that end by a Supreme Court reversal.

${ }^{6}$ This is certainly true if the broad language used in Landis v. North American Co., 299 U.S. 248,254 (1936), quoted supra note 50 , can be literally interpreted. 
the existing exceptions to the general statutory rules of federal jurisdiction, Judge Hand had said that "[ $t]$ hese are all instances of a discretionary power to stay the federal action, because a proper regard for the autonomy of the states makes that course desirable." $6_{4}$ The unification of law and equity probably justifies the reference to the discretion of all judges in the federal courts.

The wide scope of the Beiersdorf case, broadly construed, is analogous to the equally sweeping holdings in the Pullman line of cases..$^{65}$ Both are probably the result of the same pressure toward a limitation of federal jurisdiction. With the exception of these two extreme extensions, the decisions of the federal courts in refusing to exercise jurisdiction can be justified as reasonable interpretations of the statutes which gave the federal courts their jurisdiction. ${ }^{66}$ The legislative grant is a broad one, and the courts would be expected to use their discretion to avoid any serious difficulties which might result from too strict an interpretation. Even from this point of view, however, neither Southern Railway nor Beiersdorf would seem to involve such difficulties as would warrant its result. As Justice Frankfurter ${ }^{67}$ and Judge Clark ${ }^{68}$ pointed out in those cases, the matters in controversy were certainly within the ambit of a federal judge's special competence. In both instances the judicial solution to the problem appears to have gone beyond the mere addition of reasonable exceptions to the general rule of jurisdiction and actually created a new statute.

Surely the proper method of solving the broader problems raised in the Southern Railway and Beiersdorf cases is not by judicial reversal of congressional action under the guise of case law reasoning. ${ }^{69}$ Legislation repealing the diversity

${ }^{64}$ Mottolese v. Kaufman, I76 F. 2d 301, 302 (C.A. 2d, I949). "[E]quity has always interfered to prevent multiplicity of suits, and the same considerations ... make equally desirable a course as near to that as the law permits." The course which the law permits is a stay of the federal suit. Tbid., at 303 .

Of course, here, as in the equity field, the breadth of the language used might be misleading. The Beiersdorf case rests on precarious grounds and may be disregarded even in the Second Circuit. And even in the event that the Supreme Court affirmed the "discretion" found in the district judges, the actual practice of the courts might not reflect a desire to curtail federal jurisdiction.

${ }_{65}$ The Southern Railway case could be taken to mean that any matter coming within the original authority of a state administrative agency must be adjudicated in the first instance only in the state courts, regardless of the presence of a constitutional issue. Similarly, the Beiersdorf case could stand for the proposition that a federal district judge has discretion to refuse to exercise jurisdiction over any case in which the convenience of the judge or the parties is not being served.

${ }^{66}$ This is, of course, not the rationale of the courts in the cases in which they have refused to exercise jurisdiction, but such an analysis does not seem unreasonable. In fact, such a rationalization of the cases would make it more possible to set a limit than if the courts continued to build one case upon another as if no statute existed.

${ }^{67}$ Alabama Public Service Comm'n v. Southern Ry. Co., 34I U.S. 34I, 36I (I95I).

${ }^{68}$ Beiersdorf v. McGohey, 187 F. 2 d 14, 16 (C.A. $2 d$, r95 I).

${ }^{69}$ See Justice Frankfurter's concurring opinion in the Southern Railway case where he argues that the courts are not privileged to interfere with and limit congressionally granted jurisdiction. Alabama Public Service Comm'n v. Southern Ry. Co., 34I U.S. 34I, 355 (I95I). 
privilege and extending the prohibition of the Johnson Act to all state statutory questions would seem a more desirable method of change. Past congressional silence on this general subject makes any such drastic change seem unlikely; but, should the pressure of litigation in the rapidly expanding area covered by federal statutes become much greater, such a change might well become a practical necessity. ${ }^{70}$

\section{REGULATION OF LABOR'S POLITICAL CONTRIBUTIONS AND EXPENDITURES: THE BRITISH AND AMERICAN EXPERIENCE}

Section 304 of the Taft-Hartley Act, ${ }^{\mathbf{X}}$ which restricts labor's political contributions and expenditures, has not achieved the goals set for it by its original proponents. The legislation was designed primarily to protect members unwilling to finance the union's political activities and to reduce what was felt to be the undue influence of unions on elected officials and elections. ${ }^{2}$ But judicial construction has narrowed its coverage and left the law uncertain. If Section 304 is to be effective in terms of the policy considerations advanced in support of its passage, new legislative action is required. Some of the problems involved in regulation of labor's financial role in politics may be illuminated by comparing the American system with pertinent British law, which is more protective of individual freedom, less restrictive of political action by unions, and operates with greater clarity and certainty.

\section{THE UNITED STATES}

Before 1936 the political contributions and expenditures of American labor were small, sporadic and of little political importance. ${ }^{3}$ In the 1936 campaign labor spent $\$ 770,324.4$ Except for a negligible amount, 5 this money was contributed to the Democratic National Committee and other committees support-

${ }^{70}$ The Supreme Court has not, of course, actually stated the rules of federal jurisdiction in the sweeping language used in the analysis of Beiersdorf and Southern Railway in note $6_{5}$ supra; nor has the Court publicly announced its intention to curtail its appellate docket. Perfect conformance by the lower courts to these cases, however, would have the same effect as such an announcement. Developments to date indicate that the present trend will not be carried far enough to seriously alter the existing rights to federal jurisdiction. See notes $37,4 \mathrm{r}$, and 64 supra.

× 6 I Stat. 159 ( 1947 ), as amended, I8 U.S.C.A. \& 6 ro (r950).

2 See United States v. CIO, 335 U.S. I06, II 5 (1948). Concurring in the CIO case, Justice Rutledge stated that a third purpose was to preserve the purity of elections. Ibid., at I34. Not stressed in Senate debate on the Section (see text and notes at notes $33-36$ infra), this objective is too general to be of aid in defining the congressional intent underlying Section $30_{4}$ more exactly.

3 Overacker, Labor's Political Contributions, 54 Pol. Sci. Q. 56 (I939).

4 Special Committee to Investigate Campaign Expenditures in 1936, Sen. Rep. No. 151 , 75th Cong. rst Sess. 127-33 (1937) (hereafter cited as the Lonegran Report). See Overacker, op. cit. supra note 3 , for description and analysis of labor's role in the campaign.

$5 \$ 4,55^{\circ}$ to the Farmer-Labor Party. Lonegran Report, at $127-33$. 